NBER WORKING PAPER SERIES

\title{
THE EFFECTS OF DEMOGRAPHIC TRENDS ON CONSUMPTION, SAVING AND GOVERNMENT EXPENDITURES IN THE U.S.
}

Michael D. Hurd

Working Paper No. 4601

\section{NATIONAL BUREAU OF ECONOMIC RESEARCH 1050 Massachusetts Avenue \\ Cambridge, MA 02138 \\ December, 1993}

Financial suppor from the Japan Foundation Center for Global Partnership is gratefully acknowledged. This paper is part of NBER's research program in Aging. Any opinions expressed are those of the author and not those of the National Bureau of Economic Research. 


\title{
THE EFFECTS OF DEMOGRAPHIC TRENDS ON CONSUMPTION, SAVING AND GOVERNMENT EXPENDITURES \\ IN THE U.S.
}

\begin{abstract}
This paper reviews and analyzes forecasts of the Social Security trust funds, government spending, medical expenditures, and other elements of aggregate income and spending. According to these forecasts, the aging of the U.S. population will require some increases in taxes to support the retirement system. It should reduce the saving rate, and the composition of output will change. By themselves, these changes seem manageable. However, the direct effocts of aging are completely dominated by the projected increases in medical expenditures. Although medical costs interact with aging, most of the increases are not related to aging. Even the moderately high forecast of medical spending will require that all increases in output between now and 2020 be devoted to the consumption of medical services, allowing no increase in any other component of consumption.
\end{abstract}

Michael D. Hurd Department of Economics SUNY, Stony Brook Stony Brook, NY 11790 and NBER 
1. Introduction

The developed countries are all forecast to have a demographic change to older populations. The change is the combined result of the temporarily high fertility rates that produced the baby boom and falling mortality rates that both increased the probability of living to 65 and increased life expectancy at 65 . Table 1 shows the percentage of the population aged 65 or over (elderly) in seven developed countries and projected percentages. The percentage is expected to increase from $12 \%$ in 1990 to $16 \%$ in 2020. Compared with some other countries the change in the U.S. is rather modest: for example, the percentage is expected to increase from $11 \%$ to $21 \%$ in Japan.

In the U.S. after 2020 the fraction of the population over age 65 is expected to increase further as the baby boom generation fully ages past 65 . However, the growth in the oldest-old population ( 85 or over) is expected to be much larger: the percentage of the population 85 or over is forecast to double by 2020 and increase by $275 \%$ by 2040 (Advisory Council, 1991a).

These demographic changes may have profound effects on the economy because the economic behavior of the elderly is very different from the nonelderly. The most obvious difference is in their labor force participation: an older population will have fewer workers per person, and so, cet.par., the economy will have lower output per person. The elderly tend to dissave whereas the working-age population saves. Thus, an older population will have a lower saving rate. The pattern of consumption by the elderly is different: they consume more medical services and less private transportation. 
But to the extent these goods are purchased in a normally functioning market, the economy should accommodate to a change in the pattern of consumption. In the U.S. the elderly are substantially supported by the government through the tax and transfer system, in particular through Social Security (the public pension system in the U.S.), through Medicare (the government health insurance system for the elderly), and through Medicaid (the government health insurance system for the poor, whose primary users are the elderly). Therefore, part of their income and some of their consumption do not arise from market transactions, but from taxation and subsidized spending. Not only may there be deadweight losses from this system, but an aging population will require increasing taxation, which may strain the political consensus underlying the programs. Thus, the future of the Social Security system has been questioned.

This is especially troubling for the elderly because of the importance of Social Security income. Table 2 shows the sources of income of the elderly in the U.S. 93\% of households in which an elderly person lived received Social Security income, compared with just $31 \%$ with income from private pensions. ${ }^{1}$ Social Security accounts for $38 \%$ of the total income, but the distribution of income is such that it is much more important to some households than this figure would suggest. The fraction of households with more than $20 \%$ of their income from Social Security is 0.82 ; the fraction with more than half of their income from Social Security is 0.55 . That is, more than half the households have more than half of their income from Social Security. These figures suggest than any uncertainty about the future of the Social Security system is a matter of concern to the elderly. 
The goal of this paper is analyze some projections of the U.S. economy to the year 2020. The main focus will be the effects of population aging arising from compositional effects and from increased life expectancy at age 65. However, in the U.S. the effects of rapidly rising medical expenditures interact with an aging population and dominate the composition of consumption and government spending in the year 2020, so they are the subject of considerable analysis. The analysis will find the effects on households, firms, and government, and how the effects interact at the macro level.

2. Social Security Administration Forecasts.

The Office of the Actuary of the Social Security Administration makes detailed forecasts of the future of the Social Security system. The greatest effort is made for the demographic variables, principally fertility rates and mortality rates, because in the long run, trends in demographics have the greatest impact on the system. Eamings, unemployment, inflation, and other macro variables are also forecast, and these variables enter a complicated forecasting model which incorporates the Social Security law. The results are forecasts of income and expenditures of the Social Security system, as well as a great number of other variables. These forecasts will be the basis of the analysis of this section.

2.1. Demographic aspects of the Social Security forecasts. 
There are three groups of forecasts. Forecast $I$ is a high income-low cost projection based on assumptions of high fertility and low increases in life expectancy. Forecast III is a low income-high cost projection based on low fertility and high increases in life expectancy. Forecast II, which is normally used, is a medium level projection.

The forecasts depend critically on the assumptions about fertility and mortality. Table 3 has summaries of the main assumptions. Between I and III, there is substantial variation in the assumptions, which has led many users of the forecasts to assume that I and III bound the possible outcomes. However, there is no reason to suppose this. For example, Manton, Singer and Stallard, 1993, and Vaupel, 1993, have population forecasting models that under some circumstances predict much larger elderly populations than the population under III.

Table 4 has life expectancies conditional on reaching age 65 . The fiscal stability of the Social Security system depends critically on conditional life expectancy: a $1 \%$ increase in life expectancy at 65 increases expected costs by $1 \%$. There is considerable variation between I and III: for example, life expectancy of females in 2040 is $20 \%$ higher under III than under I. This implies that costs will be $20 \%$ higher.

We cannot assess the reasonableness of the demographic assumptions that underlie the forecasts by comparing the predictions with actual outcomes because we have not observed the process for enough years. However, if the forecasts vary considerably from year-to-year, it would suggest that even small amounts of new information have large impacts on the forecasts. This, in tum, would suggest that the forecasts are not very reliable. Table 5 compares forecasts to the years 2000,2020 and 
2040 of life expectancy at age 65 . The forecasts were made in 1989 and 1993 so we can see how the forecasts evolved with new information. Especially for III there were rather large declines predicted in life expectancy. Take 2000 for example. The forecast of life expectancy of women 10 years in the future changed by about $3 \%$ in just four years.

Although we cannot compare the demographic forecasts with actual outcomes, we can compare some of the economic forecast with outcomes because of the shorter time scale. Table 6 summarizes such a comparison for 4-year-ahead forecasts of some economic variables. The table gives the number of observations (comparisons between predicted and realized outcomes), the percentage of the realizations that fell between the I and III forecasts, the percentage that were exactly the same as either I or III (on the boundary) and the percentage outside the range bounded by I and III. For example, there were 11 comparisons of the actual unemployment rate with the 4-year-ahead forecast unemployment rate. $36 \%$ of the realizations fell within the range given by $I$ and III, $18 \%$ were equal to the I or III forecast, and $46 \%$ fell outside the range. Therefore, one would estimate that I and III form a $36 \%$ confidence interval for 4-year-ahead forecasts of the unemployment rate. From this point of view, it is apparent that I and III do not form high-level confidence intervals of forecasts of the economic variables.

Whether this will prove to be true for the demographic variables will be seen in 20 or 30 years, but in the meantime we should probably not treat I and III as giving high-level confidence bounds. Although I will not repeat this caution later in this paper, it should be assumed that I have this in mind.

The assumptions about fertility and mortality, along with other economic and 
demographic assumptions are used in a complicated forecasting model to find future income, costs and so forth, and the number of Social Security beneficiaries and the number of workers paying into the system (covered workers). The ratio of beneficiaries to covered workers is important because it gives the number of retirees each worker supports through the Social Security tax and transfer system. Table 7 shows that even under II, the intermediated forecast, the ratio rises from 0.30 to 0.41 in 2020 to 0.51 in 2040. Without any other accompanying changes the implication is that the tax rate on each worker will have to be raised substantially. Under III the ratio increases to 0.62 by 2040 , implying that the tax rate would have to double.

2.2. Financial aspects of the Social Security forecasts.

The Social Security system is composed of three funds. They are:

The Old-Age Survivors Insurance and Disability Insurance Fund (OASDI). This fund has two parts: Old-Age Survivors Insurance (OASI) and Disability Insurance (DI). OASI primarily supports retired workers and their spouses and widows. It provides the old-age public pensions in the U.S., and it is what most people think of when they refer to Social Security. DI supports disabled workers. It is a much smaller program than OASI.

The Federal Hospital Insurance Fund (HI). This is part A of the Medicare 
system, which provides health insurance to the elderly.

The Federal Supplementary Medical Insurance Fund (SMI). This is part $\mathrm{B}$ of the Medicare system. It differs from $\mathrm{HI}$ in that the retired elderly voluntarily pay a premium to be enrolled. The premium is normally set to cover $25 \%$ of the cost of the program with the other $75 \%$ of cost coming from general Treasury funds. Almost all elderly subscribe to SMI.

The financial status of OASDI and $\mathrm{HI}$ is generally stated in terms of the income rate and the cost rate. The income rate is the percentage of the taxable payroll paid into the funds through Social Security taxes. ${ }^{2}$ The cost rate is the percentage of the taxable payroll paid in Social Security benefits. These are good measures because they are invariant to scale effects andi if they differ, they directly show how tax rates would have to change to balance the funds.

Table 8 has the income and cost rates under I, II and III, and the balance, which is the percentage of annual expenditures in the fund. In 1991 the income rate was 12.6 and the cost rate was 11.0 , indicating that the OASDI fund was accumulating monies at the rate of $1.6 \%$ of taxable payroll. The balance in the fund was $83 \%$ of annual expenditures.

Over the next 60 years the income rate is forecast to be approximately stable, but the cost rate will increase. Under I, which is based on assumptions of high fertility and high mortality, the fund remains positive over the forecast horizon, and even in 2040 
when the baby boom generation is aged $80-90$, the cost rate is only marginally greater than the income rate.

Under II the cost rate exceeds the income rate sometime between 2015 and 2020 (not shown) but because of accumulations the fund has a positive balance until sometime between 2040 and 2045 (not shown). The changes required to bring the fund into balance are not particularly large: in 2020 the tax rate would have to be increased by $1 \%$ of taxable payroll to match income with cost.

Even under III, which is based on low fertility and low mortality, the tax increases in the early part of the forecast period are rather small: an increase of 3.0 in the income rate would make income and expenditures the same in 2020.

The long-run financial situation of the funds can be found from the summarized income and cost rates. These are the expected present value of the income and cost streams normalized by the expected present value of taxable payroll. Over 1991-2040 the summarized income rate under II is 13.10 and the summarized cost rate is 13.80 . This means that the fund would just be in balance in 2040 if today the tax rate were permanently increased by $0.7 \%$ of taxable payroll. Even under III the summarized cost rate is just $2.3 \%$ of taxable payroll higher than the income rate. These figures indicate that as far as the retirement part of Social Security is concermed, the aging of the population will increase costs, but the increase is manageable.

Table 9 has the cost rates for $\mathrm{HI}$, and they have a rather different time path then the cost rates for OASDI. (The income rate is constant under current law at 2.90.) Even under II the cost rate more than doubles by 2020 . Under III, the increase is $7.9 \%$ 
of taxable payroll: this is larger than the increase under III in OASDI, even though OASDI is a much larger program. ${ }^{3}$

The income and cost rates are normalized by taxable payroll, which is about $45 \%$ of GNP. Table 10 shows OASDI and $\mathrm{HI}$ expenditures under II as a percentage of GNP. What is striking is how large the increase in $\mathrm{HI}$ is forecast to be compared with the forecast for OASDI: by $2040 \mathrm{HI}$ is forecast to consume an additional $2.4 \%$ of GNP. Even these forecasts are conservative, however, compared with some other expert forecasts which I will discuss below.

3. Forecasts by the Expert Panel.

The 1991 Advisory Council on Social Security convened a panel of economists and actuaries (the Expert Panel) to study the impact of population aging on households, government, firms and the macro economy. It was evident, however, that such a study would be incomplete without considering the evolution of health care costs because of their high rate of growth and because of the interaction between health care costs and population aging. This section will analyze some of the findings of the Expert Panel.

The panel requested that the Health Care Financing Administration (HCFA) make four forecasts or scenarios of health care costs. These forecasts used the main demographic and economic assumptions of the Social Security Administration's forecast II, but used assumptions about the evolution of health care costs different from those imbedded in I, II, and III. The four health care forecasts all were based on forecasting 
the cost and use of 18 different types of health care resources. They all were based on use by age categories so they included changes in cost due to changes in age composition. The main differences in the four scenarios come from the differences in the assumptions about the real rate of inflation of medical services and about the rate of use and intensity of use holding age constant.s

Table 11 gives examples of the differences in assumptions and use for the four forecasts. Scenario 1 is the highest cost forecast. It assumes that the real rate of health care inflation from 1970 to $1990(1.4 \%)$ will continue to 2000 and then fall to $1.2 \%$. The rate of increase in real consumption per person will continue at the 1970-1990 rate (4.7\% per year). Scenario 2 is the same as 1 except that the rate of increase in per capita consumption falls to about $4 \%$ after 2000 . Scenario 3 has lower rates of inflation and increase in use than have been observed over the last 20 years. The assumptions about health care costs in 3 are approximately the same as those in SSA's I, II and III forecasts discussed in section 2. Scenario 4 has no real medical cost inflation and no increase in use or intensity given age. That is, it shows the effects of population aging only.

In 1990 about $12.2 \%$ of GNP was consumed in medical expenditures. By 2020 this is forecast to rise to $36.0 \%$ under scenario $1,31.5 \%$ under $2,22.7 \%$ under 3 and $13.7 \%$ under 4 . A comparison of 4 with the other scenarios shows that most of the increase in these scenarios comes from assuming that past increases in cost and use will continue into the future: holding real prices, and age-adjusted use and intensity of use per person constant, spending for medical care will increase by just $1.5 \%$ of GNP. This 
is the cet.par. aging component. Of course, increasing prices and use of medical services along with population aging will have effects that are greater than the marginal increases because of interactions. Here the increases are great enough that the interactions are not just second-order effects.

It is already clear that scenario 3 and possibly 2 are not wildly improbable and that scenario 4 will be a substantial underestimate. The estimate of 1993 medical care expenditures is $14 \%$ of GNP compared with $12.2 \%$ in 1990 . If this rate of increase continues until 2000 , medical care expenditures will be about $19 \%$ of GNP, which is larger than under any of the scenarios.

In the rest of the paper I will give outcomes under scenarios 2 and 3 . Neither the panel nor I thought, however, that they necessarily bound the medical care expenditure outcomes. The other forecasting assumptions (unemployment, general inflation, demographics and so forth) are those of SSA's forecast II.

\subsection{Impact on Government}

Table 12 has OASDHI income and cost rates for the two scenarios. Income is roughly constant, but costs increase substantially: even under 3 the tax rate would have to increase by $6.7 \%$ of payroll. As we have already seen, only minority part of this is caused by OASDI $(2.9 \%$ in Table $8, \mathrm{II})$.

The impact on governmental budgets from increasing health care costs and demographics is shown in Table 13. It shows a decline in federal government purchases. 
This is caused by a decline in defense spending from $5.8 \%$ of GNP to $3.9 \%$ and some decrease in spending for education resulting from the changing age structure of the population. These decreases more than offset an increase in direct expenditures for health care by the federal government. Of course, the increases in OASDI and HI are much greater than the fall in government purchases so that the total federal budget as a percentage of GNP will increase. A larger fraction of the federal government budget will be transfers rather than direct purchases.

Under either scenario, state and local government spending will increase due to higher medical care expenditures even though there is some offset from reduced education expenditures.

\subsection{Impact on Households.}

Average real income of elderly households is forecast to increase by $47 \%$ by 2020 , mainly due to increases in Social Security benefits and pension income. Income of nonelderly households is forecast to increase by $39 \%$. When combined with the growing elderly population, these forecasts imply that a substantially greater fraction of the income in the economy will go to elderly households, about $10.6 \%$ compared with $7.4 \%$ in $19899^{\circ}$

Medical expenditures by households will rise substantially under either scenarios 2 or 3. Table 14 shows out-of-pocket medical care expenditures expressed as a percentage of median before-tax income. In 1989 a couple with median income would have spent 
about $17 \%$ of its income on out-of-pocket medical expenses. As the table shows this percentage is expected to grow substantially to $30 \%$ under scenario 2 and $23 \%$ under scenario 3. Expenditures are expected to grow even more for singles.

A major component of medical care expenditures by households is the premium for SML, even though the premium is only $25 \%$ of actual cost. Current law establishes the SMI premium for each year until 1995. The first part of Table 15 shows what the premium would be in 2020 if there is no change in the law, and it shows that the premium would cover a small fraction of actual costs. Because the historical aim has been that the premium cover $25 \%$ of costs, as it did in 1989, the second part of the table shows the premium should it cover $25 \%$ of SMI costs. This is probably more relevant. The premium will increase under scenario 3 by $359 \%$ real, and will require $7 \%$ and $9 \%$ of the median incomes of couples and singles. If this expenditure is added to the out-ofpocket of Table 14, under scenario 3 costs for couples will increase from $20 \%$ of median income to $30 \%$ and of singles from $25 \%$ to $38 \%$. This seems like a large burden indeed.

\subsection{Impact on Firms.}

Firms will have increase liabilities for pensions because of the demographic changes, but unless coverage expands greatly the increased burden should be no more than what we have seen for OASDI. Furthermore, pension growth has been in defined contribution plans, which place no liability on the firm once the contribution has been earned. 
However, firms will have substantial exposure to risks associated with medical care expenditures. Table 16 shows estimated medical care expenditures paid for by private insurance: per capita the increase under scenario 3 is $226 \%$. In that about $80 \%$ of medical insurance is associated with employment, firms can expect sharply higher expenses for medical insurance. Of course, under this scenario, workers can expect that most, if not all, of the growth in total compensation will be in fringe benefits to cover medical expenses.

\subsection{Impact in the Aggregate.}

Sources of financing medical care expenditures should change. According to Table 17, the percentage paid by Medicare will increase from $16.5 \%$ to $25.5 \%$ under scenario 3, mainly the because of the demographic changes. This is equivalent to an increases from $2 \%$ of GNP to $5.8 \%$ of GNP. Similarly, Medicaid will increase to $3 \%$ of GNP. Even though the fraction of total expenses paid by private insurance and out-ofpocket will fall, they will still increase as a fraction of GNP because of the rapid increase in total medical costs. For example, private insurance will pay $6.7 \%$ of GNP in medical care expenditures up from $4 \%$ in 1989.

The fraction of personal consumption by the elderly will change because of demographic changes, income changes and for other reasons. To get a rough idea of the magnitude, the panel divided the population into the elderly and nonelderly. The 1988 Consumer Expenditure Survey was used to find differences in the consumption patterns 
of the two groups. If incomes do not change and consumption patterns are fixed, the population changes will indicate how consumption of different commodities will change between the two groups. For example, the nonelderly consume more motor vehicles than the elderly, so aggregate consumption of motor 'vehicles should fall as the population ages. To account for income changes the panel assumed the income elasticity of each commodity group was 1.0 . Therefore, consumption by commodity group for each age group can be forecast from the income and demographic forecasts of SSA's projection 1I. Consumption of medical services is not forecast in this way; it comes from the scenarios furnished by HCFA.

Table 18 shows the shares of personal consumption by the nonelderly and by the elderly. In 1989 , non-health consumption by the elderly was $12 \%$ of their total, which was just their share in the population. However, they consumed $36 \%$ of the health care services, mainly through the transfers in Medicare and Medicaid. These transfers are, of course, not recorded as income; were they to be, the elderly would have a much larger share of total income than indicated by money income. In total the elderly consumed $15 \%$ of private consumption in 1989.

In 2020 the elderly are forecast to be $16 \%$ of the population. They will consume $15 \%$ of non-health personal consumption, but $45 \%$ of the health care services. This increase is due to the demographic changes. In total under scenario 3 the elderly will consume $21 \%$ of total personal consumption even though they will be just $16 \%$ of the population.

With such large predicted increases in medical care expenditures, it is natural to 
wonder where the increased consumption will come from. To understand the magnitude of the adjustment that would be required, the demands of govermment, consumption, investment and the foreign sector were either forecast or assumed. For example, as mentioned above, it was assumed that federal government purchases would fall from $7.7 \%$ of GNP to $6.2 \%$ (Table 13, scenario 3). Personal consumption except for health care expenditures were calculated form the assumption of an income elasticity of 1.0 . Health care expenditures come from the HCFA scenarios. The foreign sector is assumed to be in balance, and gross investment to retum to its historic level of $13 \%$ of GNP.

Table 19 has the result of these forecasts and assumptions. Personal consumption was $66.3 \%$ of GNP in $1989.30 .9 \%$ was in goods and 35.5 in services. Among consumption of services consumption of housing was $14.3 \%$ of GNP and consumption of medical services was about $8.4 \%$. Government purchases were $19.7 \%$, gross investment was $14.8 \%$ and exports were $-0.9 \%$. Under scenario 3, personal consumption will increase to $77 \%$ of GNP with most of the increase coming from higher medical care expenditures. Government purchases and gross investment will fall slightly. Because there is no residual category that makes total demand equal total supply, demand does not have to equal supply, and indeed scenario 3 shows total demand at $108.9 \%$ of supply. Under scenario 2 demand will be $116.6 \%$ of supply.

Of course, adjustments will bring supply and demand into equality. One way to see the magnitude of the adjustments that will be required is to suppose that medical care expenditures, investment, government spending and the foreign sector demands are 
met; then, all the adjustment will have to come from non-health personal consumption. Table 20 shows the allocation of per capita GNP under this assumption. Total per capita GNP increases from $\$ 20,340$ to $\$ 27,890$. Under scenario $2, \$ 8790$ will be spent on health care expenses, $\$ 1450$ on education, and so forth. Non-health personal consumption, the residual category, will be $\$ 10,990$, which is less than the 1989 level. That is, all the growth in per capita GNP between 1989 and $2020(38 \%)$ will be used to finance increases in medical care expenditures. It is hard to see that this outcome will be desired in the general population. Even under scenario 3, non-health consumption grows at a much smaller rate than GNP.

From two perspectives an older population could be expected to have a lower average saving rate than a younger population. In the first perspective, increasing the fraction of the population that is aged will increase the asset holdings of the aged population. At a constant rate of asset decumulation, a greater fraction of the savings of the working-age population will be used to purchase the assets that the elderly are selling. Thus, the average saving rate will fall. ${ }^{\top}$ In the second perspective, the life cycle hypothesis of consumption implies that the working population saves and the retired population dissaves; therefore, cet.par. increasing the fraction that is elderly should reduced the saving rate out of income. Of course, these two perspectives are really two ways of saying the same thing.

Table 21 shows estimates of the assets of elderly in 1989 and 2020 , and the resulting levels of asset decumulation. The most important assumption is about the rate of dissaving: it is taken to be $2.9 \%$ of bequeathable nonhousing wealth. This figure is 
estimated from observed wealth changes of elderly households in the 1984 Survey of Income and Program Participation (SIPP), Waves 4 and 7 (Hurd, 1991). The economy was rather stable during the mid-1980's so the rate of wealth change may well represent the desired long-run rate of change. Furthermore, the 10-year averages from the Retirement History Survey $(3.2 \%)$ are very similar to the averages from SIPP even though the economic conditions during the years of the Retirement History Survey (1969-1979) were quite different. Other panel data sets give estimates that overall are about this magnitude. ${ }^{8}$

In 1989, the elderly held about $\$ 1.6$ trillion of nonhousing bequeathable wealth. At a rate of dissaving of $2.9 \%$, they sold $\$ 46$ billion of assets, which was $2.2 \%$ of after-tax earnings. Under the assumptions given in the table, nonhousing assets of the elderly will grow to $\$ 3.7$ trillion by 2020 and the elderly will decumulate at a rate of $\$ 107$ billion per year. This is $3.0 \%$ of after-tax eamings, requiring $0.8 \%$ more of household saving. Thus, the household saving rate is projected to fall from $4.6 \%$ to $3.8 \%$.

An alternative calculation based on saving rates out of income is the following: The average one-year rate of wealth decumulation in SIPP was $2.9 \%$ from mean wealth of $\$ 75.9$ thousand, implying an excess of consumption over income of $\$ 3.8$ thousand. Net income of the elderly in 1984 was $\$ 13,200$ (Bureau of Labor Statistics, 1989), so the rate of saving out of income by the elderly was $-16.6 \%$. I will take this to be the desired or steady-state rate of saving by the elderly. By assuming that the saving rates of the elderly and nonelderly are stable over time, the effects of population aging on the aggregate saving rate can be found simply by changing the weights on the saving rates of 
each group. In 1989 the elderly were $12 \%$ of the population and their average household income was $62.3 \%$ of average household income of the population. The household saving rate out of after-tax income was $4.6 \%$. Therefore, the saving rate of the nonelderly households was $6.3 \%$. In 2020 the elderly are forecast to be $16 \%$ of the population. Under the assumption that the average income of elderly households grows by $47 \%$ and the income of nonelderly households by $38 \%$ (Advisory Council, 1991), the aggregate household saving rate will fall by $0.7 \%$ to $3.9 \%$ of after-tax household income. This is very close to the estimate from the method based on the change in asset holdings.

In view of the large variation over time in the household saving rate and the large international variation, the fall in the household saving rate from $4.6 \%$ to $3.8 \%$ or $3.9 \%$ does not seem like a large change.

\section{Conclusion}

Excluding increases in medical care expenditures, at least to the year 2020, the aging of the population in the U.S. seems to be manageable: the required increases in Social Security retirement benefits will require some but not large tax increases; the change in the mix of consumption is rather modest; the estimated effects on the aggregate saving rate are within the bounds of historical variation. The effects beyond 2020 are greater, but they are not of crisis proportions. These demographic changes and the increased requirements for retirement income are dominated by increases in 
spending for health care. Even the forecasts to 2020 probably cannot be realized because of the required reduction in other spending.

Some of the reduction in other spending may be in saving and investment. We do not know enough about saving determination at the household level to predict how a large increase in medical care expenditures financed through Social Security taxation, out-of-pocket and employers will affect saving rates; but it may noted that the fall in the U.S. saving rate coincided with the large increase in health care spending. 


\section{ENDNOTES}

1. These are almost all associated with previous employment in the private sector.

2. The taxable payroll includes most earnings and has a maximum (\$57,000 in 1993).

The combined OASI and DI tax rate is $6.20 \%$ paid by the employee and $6.20 \%$ paid by the employer. A self-employed person pays both.

3. A comparison of the cost rates shows that $\mathrm{HI}$ is only about one-fourth the size of OASDI.

4. I was a member of the panel, and I did some of the calculations reported in this section, particularly on the macro economy and saving rates.

5. Intensity of use refers to the cost of a specific encounter with the health care system. For example, holding prices constant a visit to a doctor may change because the visit takes longer, or more procedures are used.

6. Note that these figures cannot be used to make utility comparisons because elderly households are considerably smaller than nonelderly households, and because no accounting is made of nonmoney income.

7. It is of independent interest to estimate the increase in the stock of assets that will be put on the market as the population ages.

8. See Hurd, 1992, for other estimates. 


\section{REFERENCES}

1991 Advisory Council on Social Security. 1991a. "Income Security and Health Care: Economic Implications 1991-2020," Washington.

1991 Advisory Council on Social Security. 1991b. "The Social Security Technical Panel Report to the 1991 Advisory Council on Social Security, "Washington.

Bureau of Labor Statistics, 1989, "Consumer Expenditure Survey: Integrated Survey Data, 1984-86," U.S. Department of Labor, Bulletin 2333, Washington, D. C.

Grad, Susan. 1990. "Income of the Population 55 or Older, 1988," Washington: U.S. Department of Health and Human Services, Social Security Administrationm.

Hurd, Michael D. 1991. "The Income and Savings of the Elderly," typescript, Department of Economics, SUNY, Stony Brook, NY.

Hurd, Michael D. 1992. "Wealth Depletion and Life-Cycle Consumption by the Elderly," in Topics in the Economics of Aging, Ed: David Wise, Chicago: The University of Chicago Press, pp. 135-160.

Manton, Kenneth, Burt Singer and Eric Stallard. 1993. "Projecting the Future Size and Health Status of the U.S. Elderly Population," forthcoming in Further Topics in the Economics of Aging, D. Wise (editor), Chicago: University of Chicago Press.

Trustees, 1989, The 1989 Annual Report of the Board of Tnustees of the Federal OASDI Tnust Funds, Washington: U.S. Government Printing Office.

Trustees, 1991, The 1991 Annual Report of the Board of Tnustees of the Federal OASDI Tnust Funds, Washington: U.S. Government Printing Office.

Vaupel, James. 1993. "Uncertainties and New Evidence about the Prospects for Longer Life 
Expectancy," forthcoming in Further Topics in the Economics of Aging, D. Wise (editor), Chicago: University of Chicago Press. 
Table 1

Intemational Population Aging:

Percent of Population 65 or Older

\begin{tabular}{lccccccc}
\hline \hline & Canada & France & Germany & Italy & Japan & U.K. & U.S. \\
\cline { 2 - 8 } 1990 & 11 & 14 & 16 & 14 & 11 & 15 & 12 \\
2000 & 13 & 15 & 17 & 15 & 15 & 15 & 12 \\
2020 & 19 & 20 & 22 & 19 & 21 & 16 & 16 \\
\hline Source: & Advisory Council (1991a) & & & & & \\
\hline
\end{tabular}


Table 2

Sources of Income of Aged Family Units, 1988

\begin{tabular}{|c|c|c|c|c|c|c|c|}
\hline & Earnings & $\begin{array}{c}\text { Social } \\
\text { Security }\end{array}$ & $\begin{array}{c}\text { Other } \\
\text { public } \\
\text { pensions }\end{array}$ & $\begin{array}{l}\text { Private } \\
\text { pensions }\end{array}$ & Assets & $\begin{array}{c}\text { Public } \\
\text { assistance }\end{array}$ & Other \\
\hline $\begin{array}{l}\text { Fraction with } \\
\text { income from } \\
\text { source }\end{array}$ & 0.22 & 0.93 & 0.16 & 0.31 & 0.72 & 0.05 & \\
\hline $\begin{array}{l}\text { Fraction of total } \\
\text { income }\end{array}$ & 0.17 & 0.38 & 0.10 & 0.08 & 0.25 & 0.01 & 0.02 \\
\hline $\begin{array}{l}\text { Fraction with } \\
\text { more than } 20 \% \\
\text { of total income } \\
\text { from source }\end{array}$ & 0.16 & 0.82 & 0.10 & 0.15 & 0.19 & 0.05 & \\
\hline $\begin{array}{l}\text { Fraction with } \\
\text { more than half of } \\
\text { total income } \\
\text { from source }\end{array}$ & 0.09 & 0.55 & 0.05 & 0.02 & 0.06 & 0.02 & \\
\hline Source: Grad (199 & & & & & & & \\
\hline
\end{tabular}


Table 3

Assumptions for Alternative Social Security Administration Demographic Projections

\begin{tabular}{lcccccc}
\hline \hline & \multicolumn{3}{c}{ Fertility Rate (births per woman) } & \multicolumn{3}{c}{ Age-adjusted death rate } \\
\cline { 2 - 7 } Alternative: & I & II & III & I & II & III \\
\hline 1990 & 2.05 & 2.05 & 2.05 & 785 & 792 & 800 \\
2000 & 2.12 & 2.00 & 1.87 & 754 & 723 & 739 \\
2020 & 2.20 & 1.90 & 1.60 & 714 & 633 & 560 \\
2040 & 2.20 & 1.90 & 1.60 & 679 & 573 & 475 \\
\hline Source: & Trustees' Report, 1991 & & & & \\
\hline
\end{tabular}


Table 4

Life Expectancy at Age 65

\begin{tabular}{lcccccc}
\hline & \multicolumn{3}{c}{ Males } & \multicolumn{3}{c}{ Females } \\
\cline { 2 - 7 } Alternative: & I & II & III & I & II & III \\
\hline 1990 & 15.2 & 15.3 & 15.3 & 18.9 & 19.0 & 19.0 \\
2000 & 15.3 & 15.9 & 16.4 & 18.9 & 19.6 & 20.2 \\
2020 & 15.6 & 16.7 & 18.0 & 19.1 & 20.4 & 21.9 \\
2040 & 15.9 & 17.5 & 19.5 & 19.5 & 21.3 & 23.5 \\
\hline Source: & Trustees' Report, 1991 & & & & \\
\hline
\end{tabular}


Table 5

Forecasts of Life Expectancy at Age 65

\begin{tabular}{lccccccc}
\hline \hline & & \multicolumn{2}{c}{ I } & \multicolumn{2}{c}{ II } & \multicolumn{2}{c}{ III } \\
\cline { 3 - 8 } $\begin{array}{l}\text { Year of } \\
\text { forecast }\end{array}$ & $\begin{array}{c}\text { Relevant } \\
\text { year }\end{array}$ & Men & Women & Men & Women & Men & Women \\
\hline 1989 & 2000 & 15.0 & 18.9 & 15.6 & 19.6 & 16.2 & 20.4 \\
1993 & & 15.0 & 18.8 & 15.4 & 19.4 & 15.8 & 19.9 \\
1989 & 2020 & 15.3 & 19.2 & 16.4 & 20.5 & 17.8 & 22.0 \\
1993 & & 15.2 & 18.9 & 16.3 & 20.2 & 17.4 & 21.5 \\
1989 & 2040 & 15.7 & 19.6 & 17.1 & 21.4 & 19.3 & 23.7 \\
1993 & & 15.5 & 19.2 & 17.1 & 21.1 & 19.0 & 23.2 \\
\hline \multicolumn{7}{l}{ Source: } & Trustees' Reports, 1989 and 1993 \\
\hline
\end{tabular}


Table 6

Four-year-ahead Forecasts: Percent between I and III, and outside of I and III

\begin{tabular}{lccccc}
\hline \hline & Observations & Within & On boundary & Outside & Total \\
\cline { 2 - 6 } Unemployment & 11 & 36 & 18 & 46 & 100 \\
GNP change & 11 & 18 & 0 & 82 & 100 \\
Wage change & 9 & 33 & 0 & 56 & 100 \\
Inflation & 11 & 36 & 9 & 55 & 100 \\
\hline Source: Advisory Council, 1991b & & & & \\
\hline
\end{tabular}


Table 7

Beneficiaries per 100 Covered Workers

\begin{tabular}{llll}
\hline \hline & I & II & II \\
\cline { 2 - 4 } 1991 & 30 & 30 & 30 \\
2000 & 29 & 31 & 32 \\
2010 & 31 & 33 & 36 \\
2020 & 37 & 41 & 46 \\
2030 & 43 & 49 & 56 \\
2040 & 42 & 51 & 62 \\
2050 & 41 & 52 & 67 \\
\hline Source: Trustees' Report, 1991 & & \\
\hline
\end{tabular}


Table 8

Income Rate, Cost Rate and Trust Fund Balance, OASDI

\begin{tabular}{lcccccccccc}
\hline & \multicolumn{3}{c}{ I } & \multicolumn{3}{c}{ II } & \multicolumn{3}{c}{ III } \\
\cline { 2 - 9 } 1991 & Income & Cost & Balance & Income & Cost & Balance & Income & Cost & Balance \\
\cline { 2 - 10 } 2000 & 12.6 & 11.0 & 83 & 12.6 & 11.1 & 82 & 12.6 & 11.3 & 82 \\
2010 & 12.6 & 9.7 & 303 & 12.7 & 10.9 & 229 & 12.7 & 12.3 & 139 \\
2020 & 12.9 & 11.8 & 769 & 13.0 & 14.0 & 387 & 13.1 & 16.1 & 60 \\
2030 & 13.0 & 13.3 & 772 & 13.1 & 16.3 & 235 & 13.3 & 19.5 & - \\
2040 & 13.0 & 12.8 & 844 & 13.2 & 16.6 & 40 & 13.4 & 21.1 & - \\
2050 & 13.0 & 12.3 & 981 & 13.2 & 16.7 & - & 13.4 & 22.7 & - \\
\hline Source: & Trustees' Report, 1991 & & & & & & \\
\hline
\end{tabular}


Table 9

Cost Rate of $\mathrm{HI}$

\begin{tabular}{lccc}
\hline \hline & I & II & III \\
\cline { 2 - 4 } 1991 & 2.59 & 2.61 & 2.65 \\
2000 & 2.99 & 3.52 & 4.16 \\
2010 & 3.28 & 4.56 & 6.43 \\
2020 & 3.73 & 6.20 & 10.50 \\
2030 & 4.17 & 7.84 & 14.95 \\
2040 & 4.37 & 8.55 & 16.93 \\
2050 & 4.46 & 8.72 & 17.29 \\
\hline
\end{tabular}

Source: Trustees' Report, 1991.

Note: Income rate is 2.90 
Table 10

Ratio of Expenditures to GNP

\begin{tabular}{lccc}
\hline & OASDI & HI & Total \\
\cline { 2 - 4 } 1991 & 4.8 & 1.2 & 6.1 \\
2000 & 4.7 & 1.6 & 6.3 \\
2010 & 4.8 & 2.0 & 6.8 \\
2020 & 5.8 & 2.7 & 8.5 \\
2030 & 6.7 & 3.3 & 10.0 \\
2040 & 6.6 & 3.6 & 10.2 \\
2050 & 6.6 & 3.6 & 10.1 \\
\hline
\end{tabular}

Source: Trustees' Report, 1991.

Note: II projection. 
Table 11

Medical Expenditures: Sources of Growth, Historical and Projected

\begin{tabular}{lcccc}
\hline & Scenario & $\begin{array}{c}\text { Percent real } \\
\text { medical } \\
\text { inflation }\end{array}$ & $\begin{array}{c}\text { Percent real per } \\
\text { capita medical } \\
\text { spending }\end{array}$ & $\begin{array}{c}\text { Percent of GNP } \\
\text { (end of period) }\end{array}$ \\
\cline { 2 - 5 } $1970-1980$ & 0.3 & 4.1 & 9.1 \\
$1980-1985$ & 2.1 & 4.4 & 12.2 \\
$1985-1990$ & 2.0 & 5.0 & 17.4 \\
$1990-2000$ & 1 & 1.4 & 4.7 & 17.4 \\
& 2 & 1.4 & 4.7 & 16.4 \\
& 3 & 1.2 & 4.2 & 13.1 \\
& 4 & 0.0 & 1.8 & 36.0 \\
$2000-2020$ & 1 & 1.2 & 4.7 & 31.5 \\
& 2 & 1.2 & $4.0-4.1$ & 22.7 \\
& 3 & $0.8-0.9$ & $2.7-2.6$ & 13.7 \\
\hline Source: Advisory Council, $1991 \mathrm{a}$ & & $1.3-1.1$ & \\
\hline
\end{tabular}


Table 12

OASDHI Income and Cost Rates

\begin{tabular}{lccc}
\hline & & & 2020 \\
\cline { 3 - 4 } & 1989 & 2 & 3 \\
\cline { 2 - 4 } Income & 15.5 & 15.9 & 15.7 \\
Cost & 13.7 & 22.9 & 20.4 \\
\hline
\end{tabular}

Source: Advisory Council, 1991a 
Table 13

Government Expenditures (percent of GNP)

\begin{tabular}{lccc}
\hline \hline & & \multicolumn{2}{c}{2020} \\
\cline { 2 - 4 } & 1989 & 2 & 3 \\
\cline { 2 - 4 } Federal & 14.3 & 20.4 & 15.8 \\
Purchases & 7.7 & 6.5 & 6.2 \\
HI \& SMI & 2.0 & 8.1 & 5.8 \\
OASDI & 4.6 & 5.8 & 5.8 \\
State \& local & 12.0 & 13.7 & 12.7 \\
\hline Source: Advisory Council, 1991a & & \\
\hline
\end{tabular}


Table 14

Out of Pocket Medical Expenditures by the Elderly:

Percent of Median Income

\begin{tabular}{lrcc}
\hline \hline & & & 2020 \\
& 1989 & 2 & 3 \\
\cline { 2 - 4 } Couples & 17 & 30 & 23 \\
Singles & 21 & 40 & 29 \\
\hline Source: Advisory Council, 1991a & & \\
\hline
\end{tabular}


Table 15

SMI Premiums

\begin{tabular}{lccc}
\hline \hline & & \multicolumn{2}{c}{2020} \\
\cline { 2 - 4 } & 1989 & 2 & 3 \\
\cline { 2 - 4 } & 298 & 377 & 377 \\
$\begin{array}{l}\text { A. Current Law } \\
\text { Annual premium (1988\$) } \\
\begin{array}{l}\text { Percent of SMI cost } \\
\text { B. Premium covers 25\% of cost }\end{array}\end{array}$ & 25 & 7 & 10 \\
$\quad \begin{array}{l}\text { Annual premium (1988\$) } \\
\text { Percent of median income }\end{array}$ & 298 & 1450 & 1070 \\
$\quad \begin{array}{l}\text { Couples } \\
\quad \text { Singles }\end{array}$ & 3 & 9 & 7 \\
\hline Source: Advisory Council, 1991a & 4 & 12 & 9 \\
\hline
\end{tabular}


Table 16

Health Expenditure Paid by Private Insurance

\begin{tabular}{lccc}
\hline \hline & & \multicolumn{2}{c}{2020} \\
\cline { 2 - 4 } & 1989 & 2 & 3 \\
\cline { 2 - 4 } Amount (1990\$ billions) & 222 & 866 & 618 \\
Per capita (1990\$) & 854 & 2707 & 1930 \\
\hline Source: Advisory Council, 1991a & & & \\
\hline
\end{tabular}


Table 17

Sources of Funds for Medical Spending: Percent Distribution

\begin{tabular}{lccc}
\hline \hline & & & 2020 \\
\cline { 3 - 4 } & 1989 & 2 & 3 \\
\cline { 2 - 4 } Medicare & 16.5 & 25.8 & 25.5 \\
Medicaid & 11.2 & 13.4 & 13.3 \\
Other government & 14.4 & 11.2 & 11.8 \\
Private insurance & 33.1 & 29.7 & 29.4 \\
Out-of-pocket & 20.5 & 16.2 & 16.3 \\
Other private & 4.4 & 3.7 & 3.6 \\
Total & 100.0 & 100.0 & 100.0 \\
Total medical & 12.2 & 31.5 & 22.7 \\
(percent of GNP) & & & \\
\hline Source: Advisory Council, 1991a & & \\
\hline
\end{tabular}


Table 18

Shares of Personal Consumption (percent) by Age

\begin{tabular}{lccc}
\hline \hline & & & 2020 \\
\cline { 3 - 4 } & 1989 & 2 & 3 \\
\cline { 2 - 4 } Non-health & 88 & 85 & 85 \\
Under 65 & 12 & 15 & 15 \\
65 or over & & & \\
Health & 64 & 55 & 55 \\
Under 65 & 36 & 45 & 45 \\
65 or over & & & 79 \\
Total & 85 & 77 & 21 \\
Under 65 & 15 & 23 & \\
65 or over & & & \\
\hline Source: Advisory Council, $1991 \mathrm{a}$ & & \\
\hline
\end{tabular}




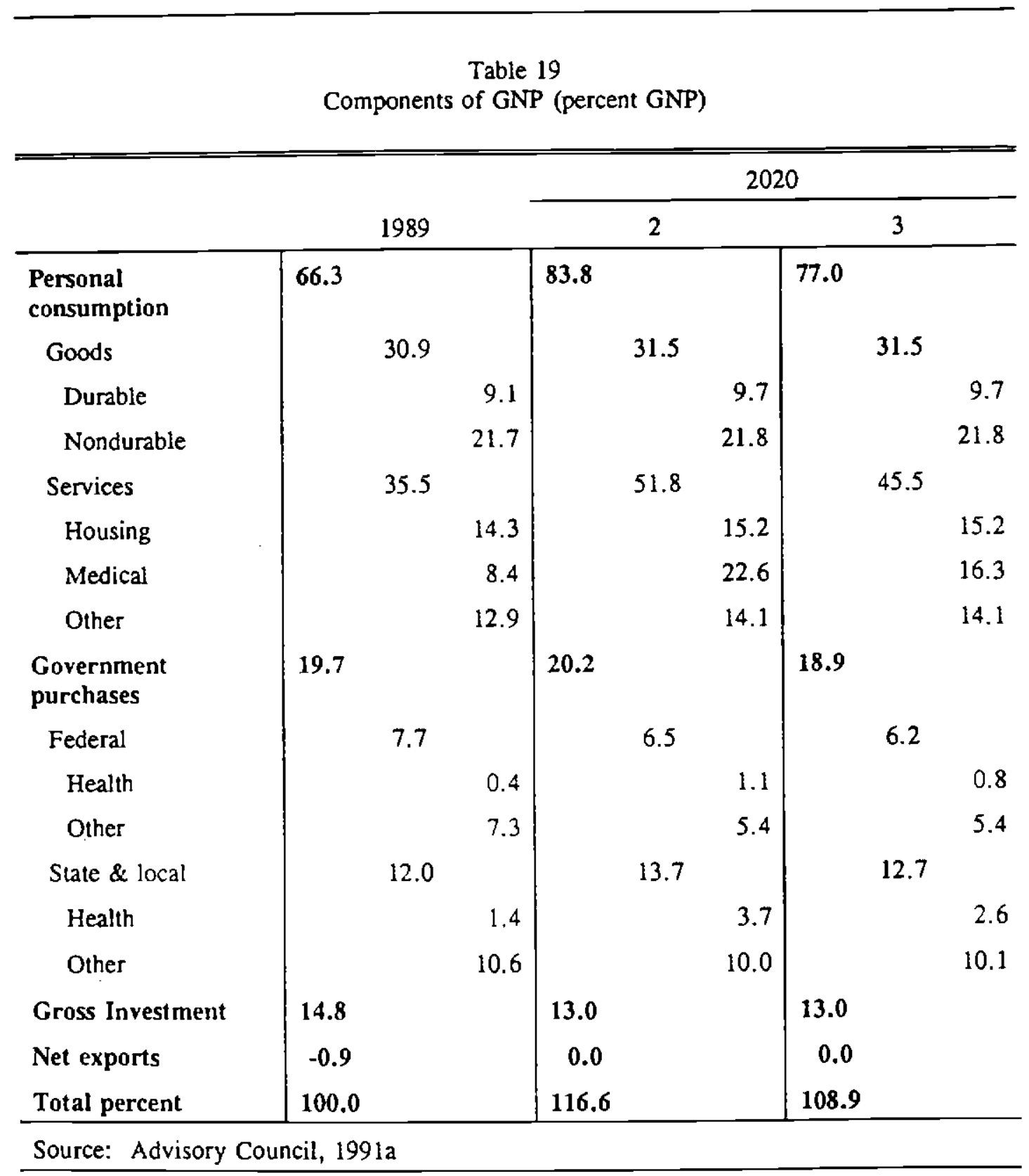


Table 20

Adjustment in Personal Consumption:

Per Capita Allocation (1989\$)

\begin{tabular}{lccc}
\hline & & \multicolumn{2}{c}{2020} \\
\cline { 3 - 4 } & 1989 & 2 & 3 \\
\cline { 2 - 4 } Health . & 2360 & 8790 & 6330 \\
Education & 1220 & 1450 & 1450 \\
Government (excl. medical) & 2600 & 3040 & 3040 \\
Investment & 3010 & 3630 & 3630 \\
Non-health personal consumption & 11080 & 10990 & 13450 \\
Total & 20340 & 27890 & 27890 \\
\hline Source: Advisory Council, 1991a & & \\
\hline
\end{tabular}


Table 21

Asset Decumulation and the Saving Rate

\begin{tabular}{|c|c|c|c|c|}
\hline & \multicolumn{2}{|c|}{1989} & \multicolumn{2}{|c|}{2020} \\
\hline & A mount & Source & Amount & Source \\
\hline Assets of elderly & $1.6 \times 10^{12}$ & A.C. & $3.7 \times 10^{12}$ & Calculation \\
\hline Asset decumulation & $0.04 \times 10^{12}$ & $\begin{array}{l}\text { Calculation: } 2.9 \% \\
\text { rate of decumulation } \\
\text { (Hurd, 1991) }\end{array}$ & $0.107 \times 10^{12}$ & $\begin{array}{l}\text { Calculation: } 2.9 \% \\
\text { rate of decumulation } \\
\text { (Hurd, 1991) }\end{array}$ \\
\hline After-tax eamings & $2.1 \times 10^{12}$ & A.C. & $3.6 \times 10^{12}$ & A.C. \\
\hline $\begin{array}{l}\text { Asset decumulation } \\
\text { out of after-tax } \\
\text { eamings }\end{array}$ & $2.2 \%$ & Calculation & $3.0 \%$ & Calculation \\
\hline $\begin{array}{l}\text { Household saving } \\
\text { rate }\end{array}$ & $4.6 \%$ & A.C. & $3.8 \%$ & Calculation \\
\hline
\end{tabular}

Source: A.C. = Advisory Council, $1991 \mathrm{a}$

Calculated as the product of 1989 assets, real per capita GNP growth of $1.01 \%$ per year and $1.8 \%$ growth in the elderly population. 